\title{
Anchovy population expansion in the North Sea
}

\author{
Pierre Petitgas ${ }^{1, *}$, Jürgen Alheit ${ }^{2}$, Myron A. Peck ${ }^{3}$, Kristina Raab ${ }^{4}$, Xabier Irigoien ${ }^{5}$, \\ Martin Huret ${ }^{1}$, Jeroen van der Kooij ${ }^{6}$, Thomas Pohlmann ${ }^{7}$, Carola Wagner ${ }^{2}$, \\ Iratxe Zarraonaindia ${ }^{8}$, Mark Dickey-Collas ${ }^{4}$ \\ ${ }^{1}$ Ifremer, rue de l'île d'Yeu, 44300 Nantes, France \\ ${ }^{2}$ Leibniz Institute for Baltic Sea Research Warnemünde, Seestr. 15, 18119 Warnemünde, Rostock, Germany \\ ${ }^{3}$ Institute of Hydrobiology and Fisheries Science, University of Hamburg, Olbersweg 24, 22767 Hamburg, Germany \\ ${ }^{4}$ IMARES (Institute for Marine Resources and Ecosystem Studies), PO Box 68, 1970 AB muiden, The Netherlands \\ ${ }^{5}$ AZTI-Tecnalia, Herrera kaia z/g, 20110 Pasaia, Gipuzkoa, Spain \\ ${ }^{6}$ CEFAS (Centre for Environment, Fisheries and Aquaculture Science), Pakefield Road, Lowestoft NR33 0HT, UK \\ ${ }^{7}$ IFM (Institute of Oceanography), University of Hamburg, Bundesstr. 53, 22457 Hamburg, Germany \\ ${ }^{8}$ University of Basque Country, Bo Sarriena z/g, 48940 Leioa, Bilbao, Spain
}

ABSTRACT: The abundance and spatial occupation of European anchovy Engraulis encrasicolus have increased in the North Sea since the mid-1990s. We use a cross-disciplinary approach combining genetics, transport modelling, survey time series analyses and physical oceanographic modelling to investigate 3 hypotheses on the reasons for this change. Evidence from connectivity studies suggests that the population of North Sea anchovy is separate from that in the Bay of Biscay. The recruitment pulses observed in survey data fit a life cycle which includes spawning in early summer and larval development in late summer. This also supports the concept of population expansion originating from local remnant population(s). In terms of growth physiology, suitable thermal windows have expanded, making conditions more favourable for life cycle closure and population persistence/productivity. In addition to the increased frequency of warm summers, which favour larvae and juvenile growth, the decrease in the number of severe winters is also likely to improve overwinter survival. Overall, the evidence supports the hypothesis that the increase in anchovy abundance originated from the improved productivity of existing populations. This increase was associated with an expansion in thermal habitats and is probably not due to a northward shift in the distribution of southern conspecifics.

KEY WORDS: Climate variability $\cdot$ Small pelagic fish • Regime shift $\cdot$ Temperature $\cdot$ Anchovy $\cdot$ North Sea

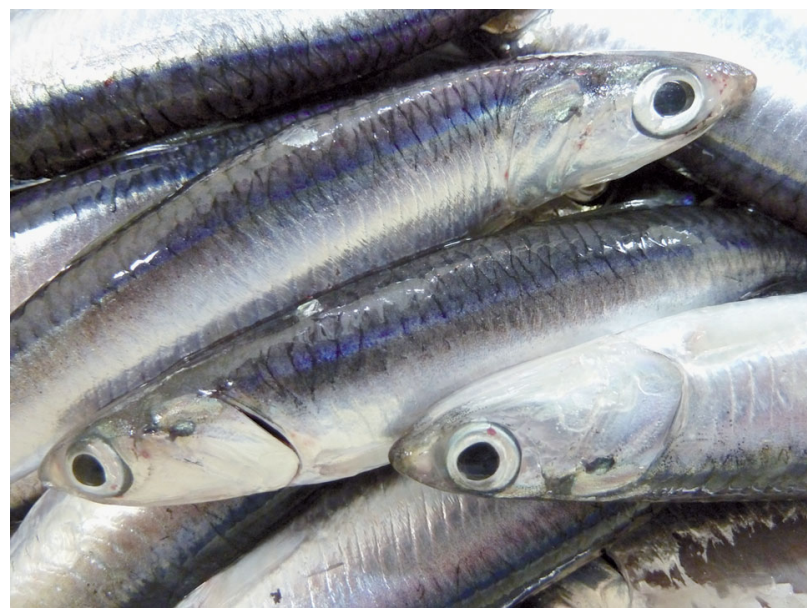

The recent increase in North Sea anchovy Engraulis encrasicolus most likely stems from climate-driven improvement in recruitment to remnant sympatric populations.

Photo: Jeroen Van Der Kooij, CEFAS

\section{INTRODUCTION}

Climate change has affected the distribution of fish populations by different mechanisms, including direct displacement of populations into novel areas and increased productivity of fringe components of populations (Beare et al. 2004, Rijnsdorp et al. 2009). The European anchovy Engraulis encrasicolus has recently been identified as a species that may have 
exhibited climate-driven changes of this nature in the North Sea, the northern boundary of this Lusitanian species (Engelhard et al. 2011). Anchovy abundance in the North Sea has fluctuated, with periods of high abundance being followed by periods of near absence (Aurich 1953). Interestingly, the periods of appearance coincide with warm phases of the Atlantic Multi-decadal Oscillation (AMO) in the last century, indicating that climate variability likely plays an important role in anchovy dynamics in the North Sea. Data from trawl surveys and commercial information landings have indicated a dramatic increase in anchovy abundance since the mid-1990s after a period of absence (Beare et al. 2004). However, the mechanisms leading to this phenomenon are not known. The aim of this study is to evaluate different hypotheses explaining why anchovy have exhibited these particular dynamics in the North Sea, to synthesise available knowledge and to provide evidence in support of the most probable scenario explaining the recent increase of this species in that ecosystem.

\section{CONTEXT OF CHANGE}

\section{Changing environment}

To investigate how the physical environment of the North Sea has changed over the last $50 \mathrm{yr}$, we used a multi-decadal (1948 to 2007) hindcast of the hydrodynamic model 'HAMSOM' (Pohlmann 2006, Meyer et al. 2011). The model was driven by 6-hourly air temperature, humidity, cloud cover, precipitation, sea level pressure and near-surface wind speed and direction from the National Centers for Environmental Prediction (NCEP) and National Center for Atmospheric Research (NCAR) global atmospheric reanalysis. The annual heat content of the North Sea varied between 330 and $366 \times 10^{6} \mathrm{~J} \mathrm{~m}^{-3}$, with mean values being highest in the summer and lowest in the winter months. Inter-annual variation was highest during the winter and spring seasons. A period of increased heat content started in the late 1990s. Changes in North Sea sea surface temperature (SST) from 1949 to 1987 were relatively small (less than $0.1^{\circ} \mathrm{C}$ decade $^{-1}$ negative trend), whereas a strong increase of up to $0.5^{\circ} \mathrm{C}$ decade ${ }^{-1}$ occurred from 1987 to 2007 . The strongest warming occurred in the German Bight $\left(1.0^{\circ} \mathrm{C}\right.$ for 1987 to 2007$)$, compared to smaller increases in the central $\left(0.3\right.$ to $\left.0.4^{\circ} \mathrm{C}\right)$ and the northern $\left(0.1\right.$ to $\left.0.3^{\circ} \mathrm{C}\right)$ North Sea (ICES 2010). However, unlike general heat content and SST, no longterm (or recent) changes in the dynamics of the ther- mocline strength (defined here as the maximum vertical temperature gradient with a threshold at $0.1^{\circ} \mathrm{C}$ $\mathrm{m}^{-1}$ ) were observed in the modelled time series (Meyer et al. 2011). This lack of change in the North Sea thermocline dynamics partly explains why time series analyses have not found strong phenological shifts in primary production even though changes in the dominant phytoplankton groups have been reported (see references in ICES 2010).

A shift in zooplankton from a typical cold-boreal to a warm-temperate community occurred in the late 1980s (e.g. Beaugrand 2004, Kirby et al. 2007). This included a shift in the dominant Calanus congener, an influx of oceanic species, an increase in warmwater zooplankton species and a shift from holoplankton to meroplankton dominance. Changes in zooplankton species composition have also been associated with phenological changes potentially affecting the matchmismatch dynamics between zooplankton and their predators (Alheit et al. 2005). Within upper trophic levels, shifts in fish species have also been documented, with an increase in species with southern affinities and or movements of some species to greater depths (Perry et al. 2005, Rijnsdorp et al. 2009). These changes in physical and biological factors defined a regime shift in 1988/89 (Weijerman et al. 2005) and coincided with an abrupt change in the winter North Atlantic Oscillation (NAO) index. The NAO is the most pronounced signal describing climate-driven variability on decadal time scales in the region (Hurrell \& Deser 2010). After the mid-1990s, the pressure centres of the NAO (Icelandic Low and the Azorian High) moved north-eastward. These atmospheric processes were accompanied by simultaneous changes in a number of large-scale water currents in the northeast Atlantic (Häkkinen \& Rhines 2004).

Although no causal relationship can be ascertained, climate-driven changes in various ecosystem components appear significant. Local and large-scale changes occurred in the North Sea environment. In addition, changes in water temperature appeared to be associated with several of these profound ecosystem changes, and these are investigated in the present study as the potential environmental driver.

\section{Fluctuations in anchovy catches and abundance}

Anchovy have historically occurred in the North Sea (Aurich 1953). In recent, more temperate times, the largest northern anchovy spawning area was in the Zuiderzee (Fig. 1 inset). This estuary supported a dedicated anchovy fishery from at least the last 


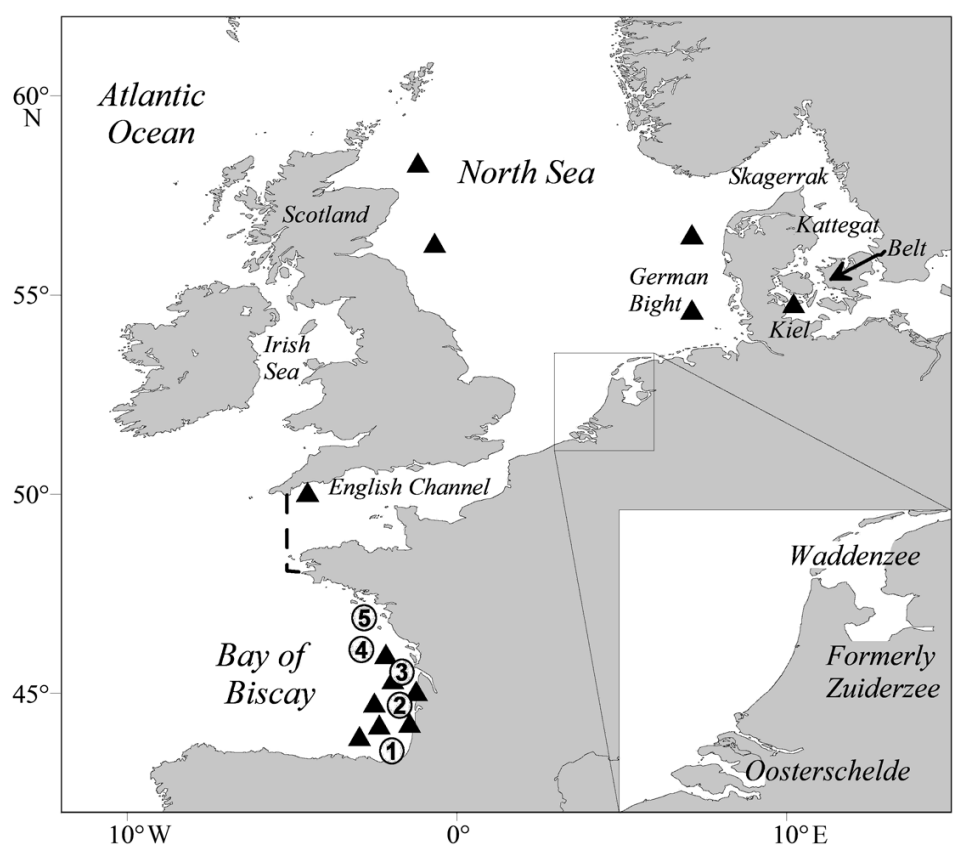

Fig. 1. Study area, including the North Sea and Bay of Biscay; inset: Dutch coastline showing area where the small local persistent population was found. Five spawning (release) locations for the ichthyoplankton transport modelling are shown (Locations 1 to 5). Triangles denote the location of anchovy sampled for genetic analysis. The dashed line represents the boundary between the English Channel and the Bay of Biscay

tional Bottom Trawl surveys of the North Sea (Fig. 2d). Anchovy in the north of their distribution appear to spawn exclusively in nearshore and estuarine areas where young larvae have been captured in good condition (Kanstinger \& Peck 2009).

\section{HYPOTHESES FOR DRAMATIC INCREASE OF ANCHOVY ABUNDANCE}

We treat the observed increase in abundance of anchovy in the North Sea as a colonisation event. The spatial expansion of a species can be explained by allopatry (colonisers coming from elsewhere) or sympatry (recruitment pulses of an adult local remnant population). In the case of North Sea anchovy, allopatric colonisation can occur through passive transport of eggs or larvae that originate from areas outside the North Sea (Fig. 1), or by actively migrating adults. The sympatric hypothesis amounts to the increased survival of progeny that resulted from spawning in the North Sea, leading to life cycle completion and an increase in numbers of adult fish. To test which of these 3

decades of the 19th century until 1932, when the estuary was closed off from the sea (Cunningham 1890, Boddeke \& Vingerhoed 1996). Despite high inter-annual variability, yearly catches occasionally exceeded $10000 \mathrm{t}$. Anecdotal evidence suggests that anchovy were also caught off the south coast of England at the end of the 19th century (Cunningham 1890) and were spawning in the German Bight in the late 1940s (Aurich 1953). After the closure of the Zuiderzee, smaller anchovy spawning areas persisted in the Oosterschelde estuary in the Netherlands and in the western Dutch Waddenzee (Boddeke \& Vingerhoed 1996; Fig. 1) with annual catches up to $1000 \mathrm{t}$ between the 1930s and 1960s (Fig. 2). Anchovy were also recorded in Danish waters (the Belt area) during the 1930s and 1940s (Heegaard 1947). All landing records from the 20th century confirm high inter-annual variability (Fig. 2).

In the latter half of the 20th century, anchovy were only rarely found in the North Sea. Research survey time series suggest low numbers between the 1930s and 1960s and from the 1970s onwards (Beare et al. 2004). In the 1990s, abundance appeared to increase again in the North Sea (Beare et al. 2004; Fig. 2d) as well as in adjacent regions (Armstrong et al. 1999). The species is now regularly caught in the Interna- hypotheses applies to the North Sea anchovy scenario, we translated their implications into the specific life cycle dynamics of anchovy.

\section{Hypothesis 1}

$H_{1}$ : A remnant population exists in the North Sea which has recently exhibited increased recruitment pulses.

In this case scenario, anchovy would have been able to complete a full life cycle in the North Sea. They would have been present in low numbers and in isolated areas before the newly recorded increase. The first signal of increased abundance would be in the recruits (i.e. smaller length classes would exhibit the first increase). Genetic differences would be expected between the North Sea and Bay of Biscay stocks. There would be no evidence of connectivity between the populations.

\section{Hypothesis 2}

$H_{2}$ : An allopatric population has seeded the North Sea by an introduction of early life stages. 

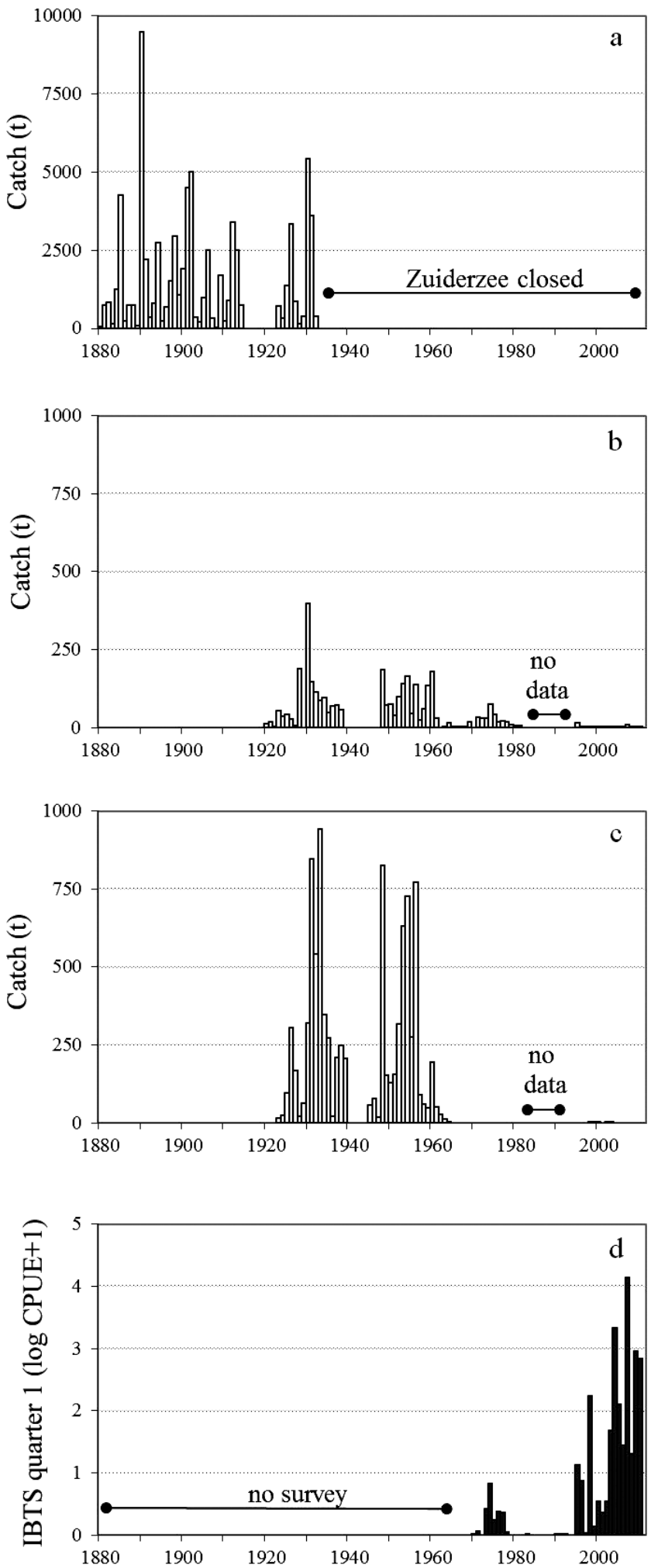

Fig. 2. Engraulis encrasicolus. Long-term anchovy records in the North Sea: annual landings by Dutch coastal fisheries from 1880 to 2010. (a) Zuiderzee, (b) Waddenzee, (c) Oosterschelde (see Fig. 1), and (d) catch per unit effort (CPUE) from the international bottom trawl survey (IBTS, Quarter 1)
The first signal of increased abundance would be in the recruits, i.e. smaller length classes would show the first increase. There would be no genetic differentiation between the North Sea and Bay of Biscay stocks. Lagrangian drift model simulations would predict larval transport into the English Channel and eventually the North Sea from the Bay of Biscay.

\section{Hypothesis 3}

$H_{3}$ : An allopatric population has seeded the North Sea by active adult migrations.

The first signal of increased abundance would be in the adults, i.e. larger length classes would show the first increase. There would be no genetic differentiation between the North Sea and Bay of Biscay stocks. However, Lagrangian drift model simulations would predict larval transport into the English Channel and eventually the North Sea from the Bay of Biscay.

We assessed the validity of each of the 3 hypotheses by compiling evidence from genetic studies, larval transport modelling, survey time series and physical models. Also, we investigated how suitable thermal habitats for anchovy spawning and larval survival may have increased in the North Sea based on physiological considerations. Each approach is considered one at a time in the following sections, building evidence for and against each hypothesis. This weight-of-evidence approach allows us to synthesise likely explanations for the observed increase in North Sea anchovy abundance in recent years. This cross-disciplinary approach used the best data sources available, but given the limited number of dedicated studies targeting anchovy in the North Sea, we made extra effort in validating the data.

\section{EXPLORATION OF HYPOTHESES}

\section{Connectivity}

We used 2 approaches to explore connectivity: between-population genetic structure and dispersal of early life stages (ichthyoplankton).

Genetic structure among European anchovy populations in the Mediterranean basins and adjacent waters, including the Bay of Biscay, has been studied using mitochondrial DNA (Magoulas et al. 2006), allozymes (Tudela et al. 1999, Sanz et al. 2008) and DNA microsatellites (Zarraonaindia et al. 2009). These studies showed differentiation between populations among the Mediterranean basins but similarity be- 
tween the Bay of Biscay and the NW Mediterranean. A geographically more extensive analysis was conducted, which included the English Channel and North Sea and which was based on single nucleotide polymorphisms (SNPs; Morin et al. 2004). A panel of 49 nuclear SNPs characterised by Zarraonaindia et al. (in press) was used in the present study on a total of 797 individual fish, sampled in various locations in the Bay of Biscay and the North Sea (Fig. 1). Genetic divergence between North Sea and Bay of Biscay populations was assessed by applying the $F_{\mathrm{ST}}$ statistics (Weir \& Cockerham 1984) using FSTAT software (Goudet 1995, 2001). In addition, the Bayesian modelbased clustering algorithm implemented in the software STRUCTURE v2.3.3 (Pritchard et al. 2000) was used to classify individual fishes in homogeneous groups, assuming a mixed ancestry model and correlated allele frequencies (Falush et al. 2003). The clustering algorithm was run considering different group numbers ( $\mathrm{K}=1$ to 10 ). Results indicated that the North Sea and English Channel samples were genetically homogeneous $\left(F_{\mathrm{ST}}=0.002 \pm 0.003 ; \mathrm{p}=\right.$ $0.179)$, as were those within the Bay of Biscay $\left(F_{\mathrm{ST}}=0.001 \pm 0.002 ; \mathrm{p}=0.211\right)$. However, significant genetic differences were found when comparing North Sea/English Channel samples with those from the Bay of Biscay $\left(F_{\mathrm{ST}}=0.030 \pm 0.011 ; \mathrm{p}<0.001\right)$. In addition, best clustering statistics were obtained when considering 2 groups $(\mathrm{K}=2)$ : one formed by Bay of Biscay samples and the other by North Sea/ English Channel samples (Fig. 3a). In addition, the genetic difference between the Bay of Biscay and North Sea/English Channel populations was larger than between the Bay of Biscay and NW Mediterranean populations $\left(F_{\mathrm{ST}}=0.020 \pm 0.009 ; \mathrm{p}<0.001\right)$. The fact that English Channel samples were grouped in a homogeneous cluster with those of the North Sea tends to reject the idea that the English Channel would comprise a transition zone between the Bay of Biscay and North Sea populations, since intermediate allele frequencies would then be expected in this area.

Oceanographic connections and transport of ichthyoplankton from the Bay of Biscay into the English Channel have already been reported (e.g. Kelly-Gerreyn et al. 2006). Anchovy eggs spawned in the Bay of Biscay have the potential to be transported into the English Channel (Huret et al. 2010). Here, we specifically estimated the loss of Bay of Biscay anchovy eggs into the English Channel using a Lagrangian particle tracking model described by Huret et al. (2010). Five spawning locations (1 to 5, Fig. 1) were chosen for release of particles. Most of the spawning takes place in the south
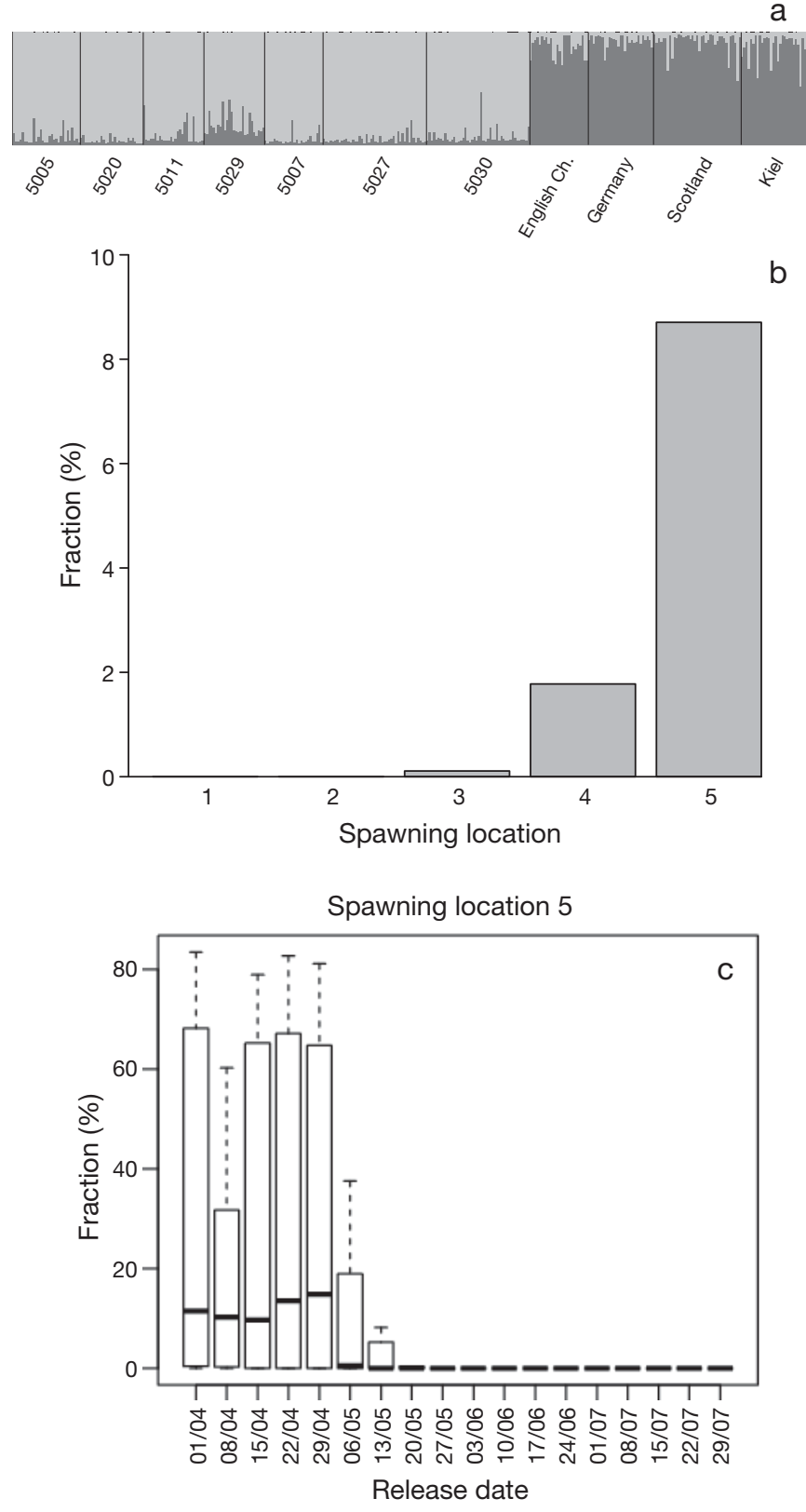

Fig. 3. Engraulis encrasicolus. Exploration of connectivity between the Bay of Biscay and North Sea anchovy populations averaged for 1996 to 2009. (a) Genetic population structure for $\mathrm{K}=2$ groups inferred with STRUCTURE v2.3.3 software. The different geographic areas that were sampled are separated by vertical lines. Numbers 5005, 5020, 5011, 5029, 5007, 5027 and 5030 refer to Bay of Biscay sample stations ( $\boldsymbol{\Delta}$ in Fig. 1). Each vertical bar represents an individual fish. The grey and black portions of the bar correspond to the individual's estimated membership fractions to the 2 clusters (light grey: Bay of Biscay; dark grey: North Sea population). (b) Statistics from the Lagrangian particle tracking model from simulations over the period 1996 to 2009. The fraction of particles transported into the English Channel from the Bay of Biscay spawning grounds is shown by spawning (release) location (see Fig. 1), and (c) in detail for spawning location 5 over the spawning season, thick black line: average fraction; error bars: $95 \%$ confidence limits 
(Locations 1 to 3, Fig. 1), particularly during the peak spawning season (May to June). Spawning in the northern areas takes place towards the end of the season (Motos et al. 1996). Particle release was simulated every week over the spawning season (April to August), and tracked for $50 \mathrm{~d}$, which is considered the mean age at metamorphosis for Bay of Biscay anchovy (Pecquerie et al. 2009, Aldanondo et al. 2010). The model was run over the period 1996 to 2009. Connectivity into the English Channel was measured as the fraction of particles arriving in the area north of $48^{\circ} \mathrm{N}$ and east of $5^{\circ} \mathrm{E}$ (Figs. $1 \& 3 \mathrm{~b}$ ). The mean fraction of particles arriving in the English Channel was generally low, between ca. $0 \%$ for spawning locations 1 to 3 , and ca. $10 \%$ for the northernmost location. The model also showed interannual and seasonal variability in the connectivity from the Bay of Biscay into the English Channel. For the northern spawning locations (4 and 5), modelled connectivity occurred early in the season (until mid-May). However, very little spawning was reported by the French PELGAS survey in April to May north of $46^{\circ} \mathrm{N}$, which was also suggested by Motos et al. (1996). Modelled connectivity is null from mid-May onwards. Thus the modelling exercise suggests that potential larval connectivity from the Bay of Biscay into the English Channel results from spawning in the northern part of the Bay, and only at the beginning of the spawning season, when spawning in fact does not occur in the north. Thus, considering the observed spatio-temporal spawning pattern (shift to the north as the season progresses), connectivity through ichthyoplankton transport may be considered highly unlikely.

Larval connectivity from the Bay of Biscay to the English Channel/North Sea areas is argued to be negligible using larval transport modelling. The other source of connectivity is via vagrant adults. However, the genetics study showed high differentiation between the 2 areas. Therefore, adult connectivity must also be considered negligible. These results provide evidence in favour of the hypothesis of an increase in abundance of local North Sea populations $\left(H_{1}\right)$, rather than a northward expansion of Bay of Biscay populations via larval transport $\left(H_{2}\right)$ or adult migration $\left(\mathrm{H}_{3}\right)$.

\section{First appearance of anchovy expansion: adults or recruits?}

To address this question, we analysed the spatial distribution and length structure of anchovy in the North Sea International Bottom Trawl Surveys series
(IBTS). The data were extracted from the International Council for the Exploration of the Sea (ICES) website portal as anchovy catch per unit effort (CPUE, numbers at length) by ICES rectangle. These data are available for Quarters 1 and 3 (Q1 and Q3; each quarter $=3 \mathrm{mo}$, where Q1 is from January to March and Q3 from July to September) of each year; since the 2 quarters can give insight into different periods of the life cycle, both were used in the analysis. Establishing whether the first expansion is due to adults or juveniles using survey data is difficult, as survey catches can be unreliable when fish have a low abundance. We therefore focused on the surveys with average log CPUE > 0.5. The averaged spatial distribution (Fig. 4) indicated that anchovy were more widely distributed across the North Sea in Q1 than in Q3, when they were more restricted to the southern North Sea and British coast. Anchovy in Q1 generally had 1 peak in length (ca. $12 \mathrm{~cm}$ ), while the length distribution of anchovy in Q3 was slightly bimodal with a strong peak at ca. $7 \mathrm{~cm}$ and a weaker peak at ca. $17 \mathrm{~cm}$ (Fig. 4). Lengths in Q3 were more variable across years, probably reflecting variability caused by recruitment pulses.

Egg surveys along the Dutch coast show that anchovy spawn in early May. In the now extinct Zuiderzee populations, which spawned in early May, anchovy reached sizes of 6 to $8 \mathrm{~cm}$ in 90 to $120 \mathrm{~d}$ (Arné 1931). Given that anchovy within the Bay of Biscay can reach 7 to $8 \mathrm{~cm}$ within ca. 60 to $80 \mathrm{~d}$, it seems likely that the anchovy caught in Q3 in the North Sea were juveniles hatched during late spring of the same year. Moreover, the otoliths of individuals caught along the Dutch coast in 2010 (May to June) were aged, and their length-at-age matched the growth pattern of Bay of Biscay anchovy (Fig. 5).

The time series of annual anchovy catches (survey CPUE) shows that although low numbers of anchovy were present in the 1970s and early 1990s (Fig. 2d), the first large increase in abundance occurred in the mid-1990s. The first time anchovy were captured in the North Sea since the 1970s was in Q3 of 1992 (Table 1). In that year, a recruitment signal was detected (length mode $<12 \mathrm{~cm}$ ), but as abundance in Q1 of the subsequent year (1993) was low, these recruits did not survive the winter. The next recruitment signal was in Q3 of 1994, and an overwinter survival of recruits is inferred from the higher abundance in Q1 of 1995. This event (1994-95) was the first largescale colonisation/recruitment by anchovy in the North Sea since the 1970s. Subsequently, there were several years of higher abundance (1994-95, 1997-98, 2002-03), and in each case, a Q3 increase preceded 

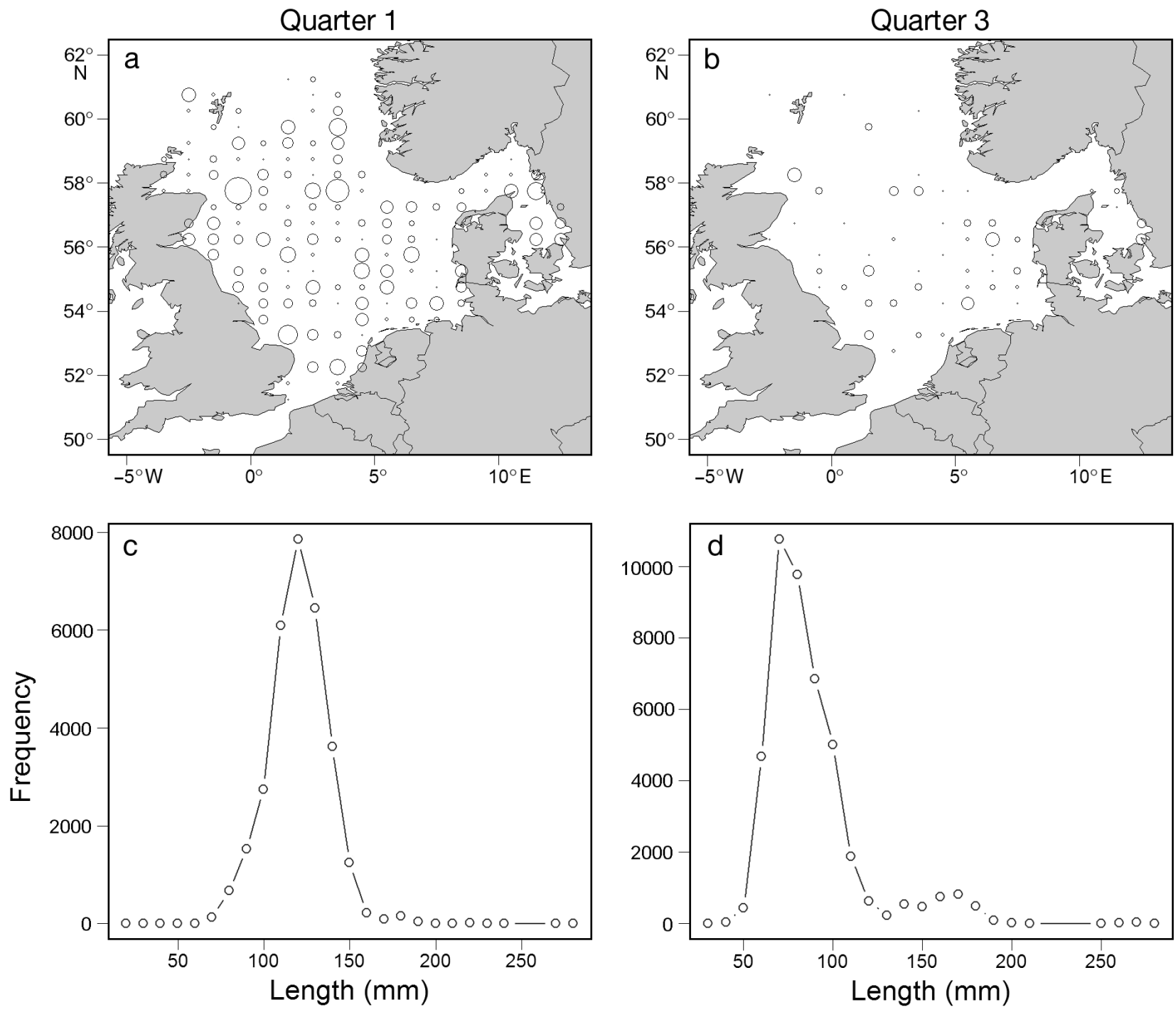

Fig. 4. Engraulis encrasicolus. (a,b) Proportional representation of the probability of presence (indicated by circle size) (mean count > 2 individuals per International Council for the Exploration of the Sea statistical rectangle) in (a) Quarter 1 (Q1; 1973 to 2010) and (b) Q3 (1990 to 2009). (c,d) Average length class frequencies of anchovy in (c) Q1 and (d) Q3 in North Sea International Bottom Trawl Survey catches. Q1 is from January to March and Q3 from July to September

an increase in Q1 of the next year (Table 1), suggesting over-wintering of recruits (sub-adults). The probability that large anchovy catches (i.e. event X: log CPUE > threshold) in summer (Q3) were followed by large anchovy catches in the subsequent winter (Q1), was high (Table 1): $\mathrm{P}\left(\mathrm{Q} 1_{t}=\mathrm{XIQ3}{ }_{t-1}=\mathrm{X}\right)=9 / 13=69 \%$ where $t$ is time. However, poor overwinter survival also occurred (i.e. event 0: $\log$ CPUE $<$ threshold) with a $40 \%$ probability $\left(\mathrm{P}\left[\mathrm{Q} 1_{t}=0 \mid \mathrm{Q} 3_{t-1}=\mathrm{X}\right]=2 / 5=40 \%\right)$, although it was estimated using a smaller number of observations (Table 1). This pattern suggests that recruitment pulses in Q3 together with overwintering survival are necessary for high catches to occur in Q1 of the following year.

\section{Thermal habitats}

One consequence of the summer warming, documented for the southern North Sea, may be a spatial and temporal expansion in favourable growth habitats. In theory, this would increase rates of larval growth and survival during summer, allowing a greater number of juveniles to grow to sufficient sizes to better survive through the winter. We examined the eco-physiology of European anchovy with emphasis on optimal and sub-optimal thermal windows for growth and survival. Since the North Sea represents the upper limit of the latitudinal range in distribution of European anchovy, we also discuss 


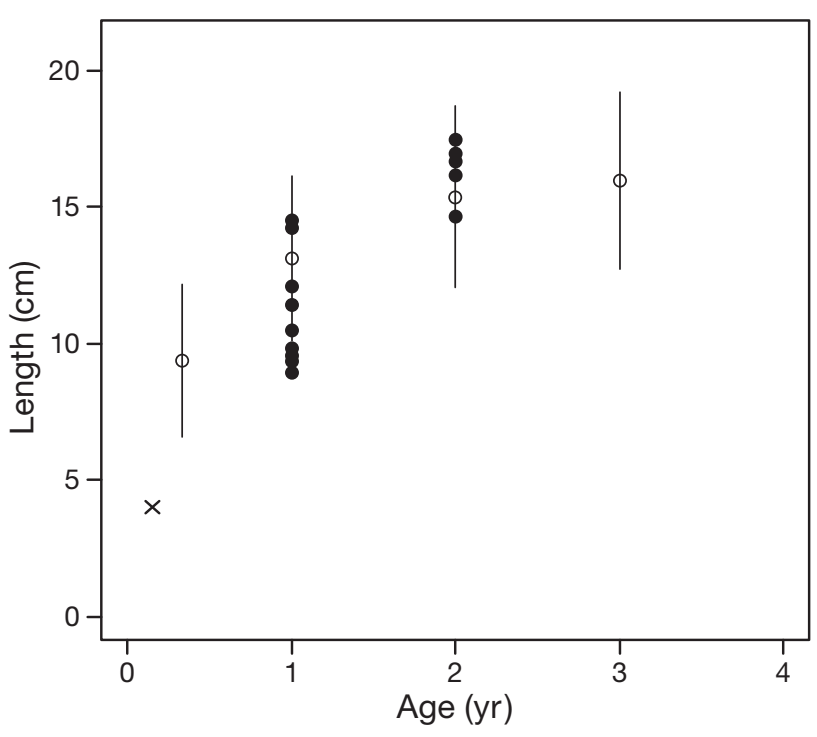

Fig. 5. Engraulis encrasicolus. Growth pattern of Biscay and North Sea anchovy. (•) North Sea anchovy. (O) Average length of Bay of Biscay anchovy obtained from 2000 to 2008 spring and autumn acoustic surveys. Bars: $95 \%$ Gaussian confidence interval around the mean. (x) Length at metamorphosis

survival constraints potentially imposed by the long duration of the winter period. Studies on other marine fish species have identified 2 principal agents affecting over-winter mortality: direct thermal stress and starvation (Hurst 2007), both of which may be size-dependent, particularly for young of the year. In most cases, obtaining large body sizes prior to the winter period increases the probability of survival (e.g. Cargnelli \& Gross 1997). The lower threshold temperature for anchovy spawning appears to be $14^{\circ} \mathrm{C}$ in European Atlantic waters, based upon observations made throughout Europe, including the Bay of Biscay (Ibaibarriaga et al. 2007), although spawning starts with warming rather than at an absolute temperature (Motos et al. 1996). Optimum larval growth temperatures are above $16^{\circ} \mathrm{C}$ (Urtizberea et al. 2008). At these temperatures, larvae would require 40 to $50 \mathrm{~d}$ to metamorphose $(4$ to $5 \mathrm{~cm}$ ) and 60 to $80 \mathrm{~d}$ to reach a size of 7 to $8 \mathrm{~cm}$ (Pecquerie et al. 2009, Aldanondo et al. 2010). In the Bay of Biscay, pre-winter juveniles would need to reach a body size of $6.6 \mathrm{~cm}$ (ICES 2009) with a condition threshold $\sim 5 \mathrm{~kJ} \mathrm{~g}^{-1}$ wet mass (Dubreuil \& Petitgas 2009) to ensure overwinter survival.

As anchovy have continuously been recorded in the Waddenzee (Boddeke \& Vingerhoed 1996), we assumed that local thermal conditions represent the minimum requirements for successful growth and survival (Fig. 6a). We also used long-term (1948 to
Table 1. Engraulis encrasicolus. Sequence of surveys with mean log catch per unit effort (CPUE) $\geq 0.5$ in the North Sea in Quarters 3 and 1 (event $X, \times$ ). (0): non-event X (mean $\log$ CPUE < 0.5); $(-)$ : no data available. Note that surveys prior to 1990 are not displayed, as few anchovy were caught (mean log CPUE < 0.5)

\begin{tabular}{|ccc|}
\hline Year & Quarter 3 & Quarter 1 \\
\hline 1990 & 0 & 0 \\
1991 & 0 & 0 \\
1992 & $\times$ & 0 \\
1993 & 0 & 0 \\
1994 & $\times$ & 0 \\
1995 & 0 & $\times$ \\
1996 & 0 & $\times$ \\
1997 & $\times$ & 0 \\
1998 & $\times$ & $\times$ \\
1999 & $\times$ & 0 \\
2000 & 0 & $\times$ \\
2001 & 0 & 0 \\
2002 & 0 & $\times$ \\
2003 & $\times$ & $\times$ \\
2004 & $\times$ & $\times$ \\
2005 & $\times$ & $\times$ \\
2006 & $\times$ & $\times$ \\
2007 & $\times$ & $\times$ \\
2008 & $\times$ & $\times$ \\
2009 & 0 & $\times$ \\
2010 & - & $\times$ \\
\hline
\end{tabular}

2007) temperature simulations from the HAMSOM oceanographic model (Meyer et al. 2011) to calculate the period (in days) during which the southern North Sea water temperatures were above and below specific high (Fig. 6b) and low (Fig. 6c) thresholds. The simulated temperatures of the southern North Sea (defined as $<55^{\circ} \mathrm{N}$ and $<50 \mathrm{~m}$ deep) suggested windows of suitable spawning temperatures $\left(T>14^{\circ} \mathrm{C}\right)$ and larval growth temperatures $\left(T>16^{\circ} \mathrm{C}\right)$ of 3 to 4 and 2 to $3 \mathrm{mo}$, respectively. Waddenzee temperature records suggested the same thermal durations. In comparison, spawning and growth windows in the South of the Bay of Biscay lasted 7 and 5 mo, respectively (Fig. 6a). In the southern North Sea, both the thermal spawning and growth windows have increased by ca. 2 to 6 wk in most years between 1989 and 2007. At the same time, the severity of winters (defined here as mean water temperatures below $6^{\circ} \mathrm{C}$ for 60 d) has markedly declined: between 1989 and 2007, only 5 years experienced severe winters, compared to $70 \%$ of the years between 1948 and 1988 . Assuming that thermal requirements for North Sea and Bay of Biscay anchovy are similar (which may not be the case due to plasticity in life history traits), suitable thermal habitats now regularly exist in the southern North Sea. Such favourable spawning and 
a

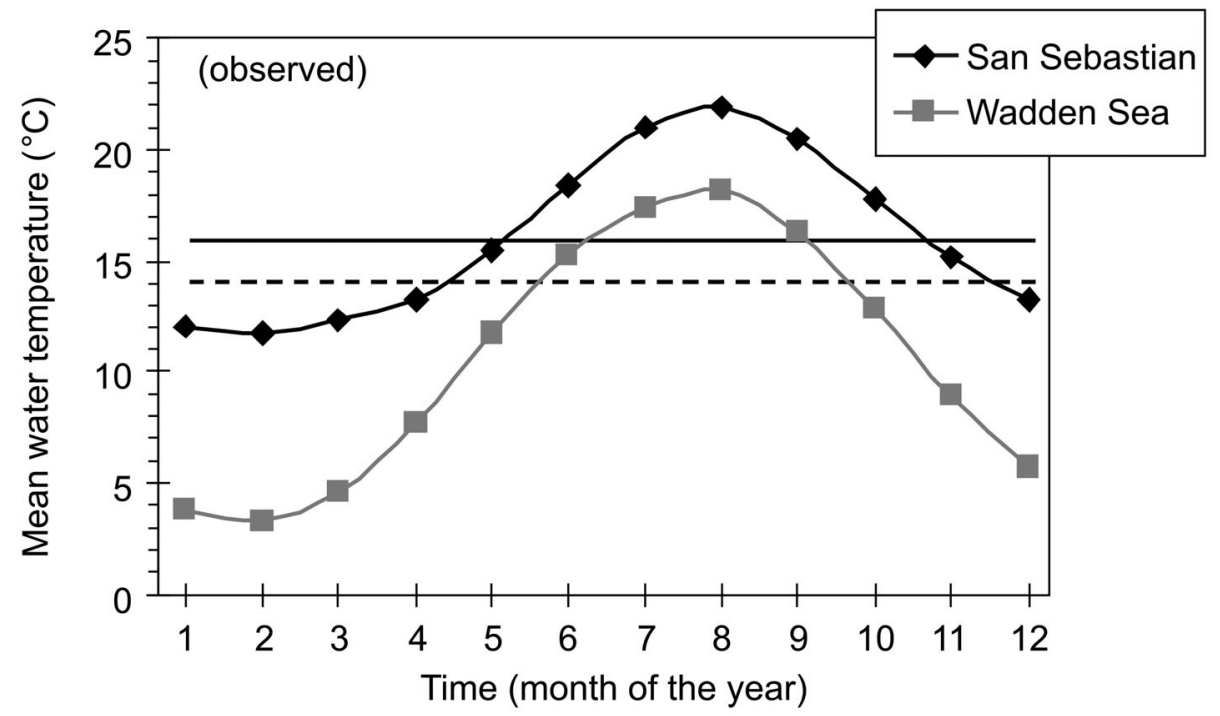

b

C

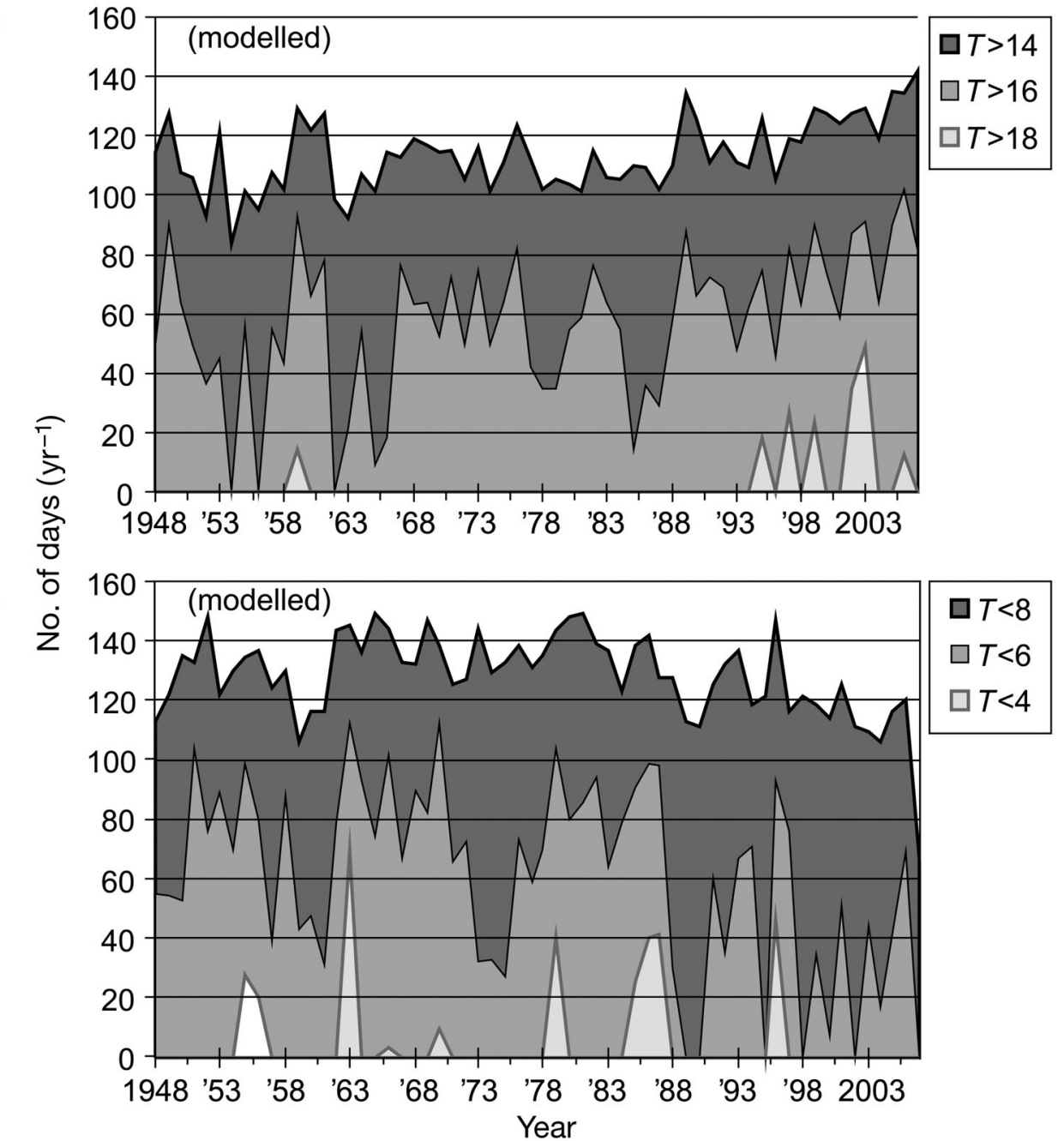

Fig. 6. Observed and model-derived thermal environments for the southern North Sea and southern Bay of Biscay. (a) Monthly climatology (1947 to 2005) observed temperature in the Waddenzee and San Sebastian. Horizontal lines indicate the lower limits for anchovy spawning $\left(14^{\circ} \mathrm{C}\right)$ and larval growth $\left(16^{\circ} \mathrm{C}\right)$ in the Bay of Biscay. (b) Number of days per year for the period 1948 to 2007 where temperature exceeded specific thresholds $\left(14,16\right.$ and $\left.18^{\circ} \mathrm{C}\right)$. (c) Number of days per year in the Waddenzee where temperature was lower than specific thresholds $\left(8,6\right.$ and $\left.4^{\circ} \mathrm{C}\right)$ 
growth conditions are prerequisites for population persistence and productivity.

The results of this exploration of eco-physiological habitats suggest that spatio-temporal variability in the width of thermal windows may strongly influence spawning, larval and juvenile survival and ultimately the recruitment success of North Sea anchovy. The optimum thermal window for growth has widened in the southern North Sea since 1989. Given the thermal biology of this species, extreme warm events are unlikely to be detrimental. However, extreme (shortterm) cold events have been correlated with massive winter mortality of some North Sea fish species (Pörtner \& Peck 2010) and could also apply to North Sea anchovy.

\section{DISCUSSION}

Previous genetic studies have identified potential differentiation within the Bay of Biscay (Sanz et al. 2008, Zarraonaindia et al. 2009). Here, such differentiation was probably outweighed by the larger difference between North Sea/English Channel and Bay of Biscay samples that appeared using SNP markers. Here, the transport modelling and genetic studies both suggest that North Sea and Bay of Biscay anchovy are separate populations. Additional information is given by otolith chemistry performed on 4 fishes from the Bay of Biscay and 3 from the North Sea (Scotland, Fig. 1) sampled in 2009. The elements ( $\mathrm{Sr}, \mathrm{Si}, \mathrm{K}, \mathrm{P}, \mathrm{Mg}, \mathrm{Cr}, \mathrm{Mn}, \mathrm{Ba}, \mathrm{Zn}, \mathrm{Co}$ ) of the otolith core were measured following the methodology documented by Aldanondo et al. (2010). A cluster analysis (Ward method, Euclidean distances) based on the concentration of the different elements clearly differentiated individuals collected off the North Sea coast of Scotland from those captured in the Bay of Biscay. This indicates that the individuals collected in the North Sea and the Bay of Biscay originated from different spawning locations. Although only 7 fish were analysed, the results agree with the genetic and transport analyses and add to the evidence in support of the local expansion hypothesis $\left(H_{1}\right)$.

The observed recruitment pulses seen in the trawl surveys suggest spring spawning and larval development in summer. They also support the concept of population expansion from recruitment pulses originating from possible remnant North Sea population(s). In terms of growth physiology, the thermal windows required also fit the seasonal schedule of spring spawning and summer larval development. In addition, the thermal windows have expanded, mak- ing conditions more favourable for life cycle closure and population persistence/productivity. Not only does the recently observed increased frequency of warm summers favour the growth of larvae and juveniles, but the decrease in severe winters likely also favours overwinter survival. The overall evidence supports hypothesis $H_{1}$, which interprets the observed increase in anchovy abundance as originating from increased productivity of a sympatric population or populations in the North Sea. The alternative hypotheses, which proposed that the increase in North Sea anchovy abundance was due to a northward shift in the distribution of southern conspecifics, were rejected.

Self-recruiting and persistent remnant populations exist in all taxa and are often isolated and sometimes genetically distinct from other populations of the same species (e.g. Garcia 2008, Galand \& Fevolden 2000). Isolated self-recruiting populations can continue to exist at low abundance and on a small spatial scale, depending on life-history or behavioural traits (Nordeng 1983, Garcia 2008). As natural collapses and recoveries of marine fish stocks are a common feature (Baumgartner et al. 1992), small contracted populations can represent the way a species may persist over geological times. Several salmonid and clupeid species are known to be able to persist in adverse conditions as self-recruiting remnant populations. Examples include Arctic charr Salvelinus alpinus (Nordeng 1983), Blackwater herring (Roel et al. 2004), Limfjord herring (Poulsen et al. 2007) and Bay of Biscay herring (all Clupea harengus) (Alheit \& Hagen 1997). Our study suggests that North Sea anchovy should be included in that list.

Small population sizes are often the consequence of restricted habitat availability (Bertrand et al. 2004). Therefore, remnant populations of short-lived and highly fecund species may dramatically increase in size when the extent of favourable habitats increases. Our study suggests that the increase in North Sea anchovy since the late 1990s is associated with the expansion of thermal habitats which supports growth and survival of pre-recruits. However, it does not explain how spatially expanded habitats may be newly colonised (Petitgas et al. 2010). We based our conclusion on a cross-disciplinary approach, which focused on stage-specific habitat requirements and the importance of life cycle closure.

Given the paucity of local studies on anchovy, our approach was to analyse an amalgam of data of differing quality. We used the IBTS series to investigate trends in anchovy abundance (as in Beare et al. 2004). Anchovy in the Bay of Biscay are generally found relatively close to the bottom during the day 
(Massé 1996) particularly in winter (Fage 1911). This may in part explain the higher catches in IBTS in Q1 and also suggests that the Q1 survey may more closely reflect patterns in anchovy abundance. It is noteworthy that anchovy are not found in the North Sea during summer pelagic fish surveys, probably because this species has migrated out of the survey area to inshore waters for spawning. The exclusively near-shore distribution of anchovy larvae as found in ichthyoplankton surveys in June/July supports this assertion (Kanstinger \& Peck 2009; IMARES unpubl. data). We therefore used the catch data from bottom trawl surveys and inferred likely processes from existing eco-physiological information of this species. However, there are gaps in the survey time series (Fig. 2), and only limited data are available on the growth and maturity of anchovy in the North Sea (Fig. 5).

In this paper, anchovy have been considered in isolation. However, the population dynamics of anchovy will also respond to and influence the dynamics of their prey, competitors and predators. Few studies have examined the link between anchovy and other components of the North Sea ecosystem. Anchovy are not currently included in multi-species North Sea models (ICES 2010) because their biomass was considered too low for the species to have a substantial impact on the food web. Moreover, there is no information on which predators consume anchovy, since large-scale stomach content sampling programs were undertaken in 1981 and 1991 when North Sea anchovy populations were low. Recent diet research has indicated that North Sea anchovy are generalist planktivores (Raab et al. 2011), suggesting that, unlike sprat Sprattus sprattus and Atlantic herring, they are opportunistic feeders and therefore less likely to be prey-limited.

We used a multi-disciplinary and integrative approach along the life cycle. Our conclusions are based on coherent results obtained from different sources, although each individually has its shortcomings. Our study has indicated the importance of suitable thermal habitats for spawning, larvae and juveniles (growth). Our analysis favours the hypothesis that the greater abundance of North Sea anchovy rose from expanding remnant populations, probably influenced by the expansion of their thermal habitat brought about by a combined action of AMO dynamics and global warming. Warming waters would likely benefit anchovy in a number of ways, including increasing (1) the duration of spawning windows, (2) larval/juvenile growth rates, and (3) overwinter survival of juveniles.
Yet, there are still gaps in our knowledge of the way the life cycle is effectively completed; in particular, we lack knowledge of seasonal migrations and how these can be newly established from a remnant coastal population. Also unknown in the North Sea are the drivers of the population dynamics of anchovy. Here, we have focused on the impact of thermal habitats, but North Sea anchovy are likely to be affected by a variety of abiotic and biotic factors, including river plumes, primary production, zooplankton, wind stress and a combination of these, as these factors influence anchovy populations in other areas (e.g. García et al. 1998, Palomera et al. 2007, Borja et al. 2008, Schismenou et al. 2008). Furthermore, beyond basic studies of population demographics, it would be beneficial to conduct targeted, eco-physiological research on anchovy, testing for potential adaptations to specific thermal habitats along a latitudinal gradient.

Acknowledgements. This manuscript is a product of the workshop on anchovy and sardine in the North Sea and adjacent areas (WKANSARNS) held under the auspices of the International Council for the Exploration of the Sea (ICES). Our exploration was helped by conversations with D. Beare, B. MacKenzie and M. Bernal. Some authors were partially funded through the EU FP7 'FACTS' project, the EU-MARINERA 'ECODRIVE' project and the ERANET MARIFISH 'REPRODUCE' project. We thank E. Hatfield for providing otoliths from North Sea anchovies captured off Scotland and P. Grellier for ageing the otoliths of the Dutch coast anchovies (Fig. 5).

\section{LITERATURE CITED}

Aldanondo N, Cotano U, Tiepolo M, Boyra G, Irigoien X (2010) Growth and movement patterns of early juvenile European anchovy (Engraulis encrasicolus L.) in the Bay of Biscay based on otolith microstructure and chemistry. Fish Oceanogr 19:196-208

Alheit J, Hagen H (1997) Long-term climate forcing of European herring and sardine populations. Fish Oceanogr 6: 130-139

Alheit J, Möllmann C, Dutz J, Kornilovs G, Loewe P, Mohrholz V, Wasmund N (2005) Synchronous ecological regime shifts in the central Baltic and the North Sea in the late 1980s. ICES J Mar Sci 62:1205-1215

Armstrong MJ, Dickey-Collas M, McAliskey M, McCurdy WJ, Burns CA, Peel JAD (1999) The distribution of anchovy (Engraulis encrasicolus) in the northern Irish Sea from 1991 to 1999. J Mar Biol Assoc UK 79:955-956

Arné P (1931) Contribution à l'étude de l'anchois (Engrualis encrasicolus) du golfe de Gascogne. Rev Trav Off Sci Tech Pêches Mar 4:153-181

Aurich HJ (1953) Verbreitung und Laichverhältnisse von Sardelle und Sardine in der südöstlichen Nordsee und ihre Veränderungen als Folge der Klimaänderung. Helgol Wiss Meeresunters 4:175-204 
Baumgartner T, Soutar A, Ferreira-Bartrina V (1992) Reconstruction of the history of Pacific sardine and northern anchovy populations over the last two millennia from sediments of the Santa Barbara Basin, California. Cal Coop Ocean Fish Invest Rep 33:24-40

Beare DJ, Burns F, Greig A, Jones EG and others (2004) Long-term increases in prevalence of North Sea fishes having southern biogeographic affinities. Mar Ecol Prog Ser 284:269-278

Beaugrand G (2004) The North Sea regime shift: evidence, causes, mechanisms and consequences. Prog Oceanogr 60:245-262

Bertrand A, Segura M, Gutiérrez M, Vasquez L (2004) From small-scale habitat loopholes to decadal cycles: a habitat-based hypothesis explaining fluctuation in pelagic fish populations off Peru. Fish Fish 5:296-316

Boddeke R, Vingerhoed B (1996) The anchovy returns to the Wadden Sea. ICES J Mar Sci 53:1003-1007

Borja A, Fontan A, Saenz J, Valencia V (2008) Climate, oceanography, and recruitment: the case of Bay of Biscay anchovy (Engraulis encrasicolus). Fish Oceanogr 17: 477-493

> Cargnelli LM, Gross MR (1997) Larger individuals emerge from winter in better condition. Trans Am Fish Soc 126: 153-156

Cunningham JT (1890) Anchovies in the English Channel. J Mar Biol Assoc UK 1:328-339

> Dubreuil J, Petitgas P (2009) Energy density of anchovy Engraulis encrasicolus in the Bay of Biscay. J Fish Biol 74: 521-534

Engelhard GH, Ellis JR, Payne MR, ter Hofstede R, Pinnegar JK (2011) Ecotypes as a concept for exploring responses to climate change in fish assemblages. ICES J Mar Sci 68:580-591

Fage L (1911) Recherches sur la biologie de l'anchois (Engraulis encrasicolus, L.). Ann Inst Oceanogr 2:1-44

Falush D, Stephens M, Pritchard JK (2003) Inference of population structure using multilocus genotype data: linked loci and correlated allele frequencies. Genetics 164: 1567-1587

Galand P, Fevolden S (2000) Population structure of Chlamys islandica in the Northeast Atlantic-northern stocks compared with a southern relict population. Sarsia 85:183-188

Garcia M (2008) Life history and population size variability in a relict plant. Different routes towards long-term persistence. Divers Distrib 14:106-113

> García A, Cortés D, Ramirez T (1998) Daily larval growth and RNA and DNA contents of the NW Mediterranean anchovy Engraulis encrasicolus and their relations to the environment. Mar Ecol Prog Ser 166:237-245

Goudet J (1995) FSTAT (version 1.2): a computer program to calculate F-statistics. J Hered 86:485-486

Goudet J (2001) FSTAT, a program to estimate and test gene diversities and fixation indices, Version 2.9.3. Available at www2.unil.ch/popgen/softwares/fstat.htm

Häkkinen S, Rhines PB (2004) Decline of subpolar North Atlantic circulation during the 1990s. Science 304:555-559

Heegaard P (1947) Investigations on the breeding season and the quantities of eggs of the food-fishes of the Kattegat and the Northern Belt Sea, 1929-1941. Medd Komm Dan Fisk Havunders 11:3-22

Huret M, Petitgas P, Woillez M (2010) Dispersal kernels and their drivers captured with a hydrodynamic model and spatial indices: a case study on anchovy (Engraulis encrasicolus) early life stages in the Bay of Biscay. Prog Oceanogr 87:6-17

Hurrell J, Deser C (2010) North Atlantic climate variability: the role of the North Atlantic Oscillation. J Mar Syst 79: 231-244

Hurst TP (2007) Causes and consequences of winter mortality in fishes. J Fish Biol 71:315-345

- Ibaibarriaga L, Irigoien X, Santos M, Motos L and others (2007) Egg and larval distributions of seven fish species in north-east Atlantic waters. Fish Oceanogr 16:284-293

ICES (International Council for the Exploration of the Sea) (2009) Report of the Benchmark Workshop on Shortlived Species (WKSHORT). ICES CM2009/ACOM:34. ICES, Copenhagen

ICES (2010) Report of the workshop on anchovy, sardine and climate variability in the North Sea and adjacent areas (WKANSARNS). ICES CM 2010/SSGRSP:04. ICES, Copenhagen

Kanstinger P, Peck MA (2009) Co-occurrence of European sardine (Sardina pilchardus), anchovy (Engraulis encrasicolus) and sprat (Sprattus sprattus) larvae in southern North Sea habitats: abundance, distribution and biochemical-based condition. Sci Mar 73(Suppl 1):141-152

Kelly-Gerreyn BA, Hydes DJ, Jegou AM, Lazure P, Fernand LJ, Puillat I, Garcia-Soto C (2006) Low salinity intrusions in the western English Channel. Cont Shelf Res 26: 1241-1257

- Kirby RR, Beaugrand G, Lindley JA, Richardson AJ, Edwards M, Reid PC (2007) Climate effects and benthicpelagic coupling in the North Sea. Mar Ecol Prog Ser 330:31-38

Magoulas A, Castilho R, Caetano S (2006) Mitochondrial DNA reveals a mosaic pattern of phylogeographical structure in Mediterranean populations of anchovy (Engraulis encrasicolus). Mol Phylogenet Evol 39:734-746

Massé J (1996) Acoustic observations in the Bay of Biscay: schooling, vertical distribution, species assemblages and behaviour. Sci Mar 60(Suppl 2):227-234

Meyer EMI, Pohlmann T, Weisse R (2011) Thermodynamic variability and change in the North Sea (1948-2007) derived from a multi-decadal hindcast. J Mar Syst 86:35-44

Morin P, Luikart G, Wayne R, Allendorf FW and others (2004) SNPs in ecology, evolution and conservation. Trends Ecol Evol 19:208-216

Motos L, Uriarte A, Valencia V (1996) The spawning environment of the Bay of Biscay anchovy (Engraulis encrasicolus L.). Sci Mar 60:117-140

> Nordeng H (1983) Solution to the 'char problem' based on Arctic char (Salvelinus alpinus) in Norway. Can J Fish Aquat Sci 40:1372-1387

> Palomera I, Olivar MP, Salat J, Sabates A, Coll M, Garcia A, Morales-Nin B (2007) Small pelagic fish in the NW Mediterranean Sea: an ecological review. Prog Oceanogr 74:377-396

> Pecquerie L, Petitgas P, Kooijman S (2009) Modeling fish growth and reproduction in the context of the Dynamic Energy Budget theory to predict environmental impact on anchovy spawning duration. J Sea Res 62:93-105

Perry AL, Low PJ, Ellis JR, Reynolds JD (2005) Climate change and distribution shifts in marine fishes. Science 308:1912-1915

> Petitgas P, Secor DH, McQuinn I, Huse G, Lo L (2010) Stock collapses and their recovery: mechanisms that establish and maintain life-cycle closure in space and time. ICES J Mar Sci 67:1841-1848 
Pohlmann T (2006) A meso-scale model of the central and southern North Sea: consequences of an improved resolution. Cont Shelf Res 26:2367-2385

Pörtner HO, Peck MA (2010) Climate change impacts on fish and fisheries: towards a cause and effect understanding. J Fish Biol 77:1745-1779

Poulsen B, Holm P, MacKenzie BR (2007) A long-term (1667-1860) perspective on impacts of fishing and environmental variability on fisheries for herring, eel, and whitefish in the Limfjord, Denmark. Fish Res 87:181-195

Pritchard JK, Stephens M, Donnelly P (2000) Inference of population structure using multilocus genotype data. Genetics 155:945-959

Raab K, Nagelkerke LAJ, Boerée C, Rijnsdorp AD, Temming A, Dickey-Collas M (2011) Anchovy Engraulis encrasicolus diet in the North and Baltic Seas. J Sea Res 65: $131-140$

Rijnsdorp AD, Peck MA, Engelhard GH, Möllmann C, Pinnegar JK (2009) Resolving the effect of climate change on fish populations. ICES J Mar Sci 66:1570-1583

Roel BA, O'Brien CM, Basson M (2004) Management options for the Blackwater herring, a local springspawning stock in the Thames Estuary. ICES J Mar Sci 61:297-307

Sanz N, Garcia-Marín JL, Viñas J, Roldán M, Pla C (2008) Spawning groups of European anchovy: population structure and management implications. ICES J Mar Sci 65:1635-1644

Editorial responsibility: Stylianos Somarakis, Heraklion, Greece
Schismenou E, Giannoulaki M, Valavanis VD, Somarakis S (2008) Modeling and predicting potential spawning habitat of anchovy (Engraulis encrasicolus) and round sardinella (Sardinella aurita) based on satellite environmental information. Hydrobiologia 612:201-214

Tudela S, García-Marín JL, Pla C (1999) Genetic structure of the European anchovy, Engraulis encrasicolus, in the north-west Mediterranean. J Exp Mar Biol Ecol 234: 95-109

> Urtizberea A, Fiksen Ø, Folkvord A, Irigoien X (2008) Modelling growth of larval anchovies including diel feeding patterns, temperature and body size. J Plankton Res 30:1369-1383

Weijerman M, Lindebom H, Zuur AF (2005) Regime shifts in marine ecosystems of the North Sea and Wadden Sea. Mar Ecol Prog Ser 298:21-39

- Weir BS, Cockerham CC (1984) Estimating F-statistics for the analysis of population structure. Evolution 38: 1358-1370

> Zarraonaindia I, Pardo MA, Iriondo M, Manzano C, Estonba A (2009) Microsatellite variability in European anchovy (Engraulis encrasicolus) calls for further investigation of its genetic structure and biogeography. ICES J Mar Sci 66:2176-2182

Zarraonaindia I, Albaina A, Iriondo M, Manzano C, Pardo M, Irigoien X, Estonba A (in press) Discovery and characterization of 90 SNPs in the European anchovy (Engraulis encrasicolus). Mol Ecol Res

Submitted: May 9, 2011; Accepted: October 16, 2011

Proofs received from author(s): December 15, 2011 